\title{
Facebook as a Source of Informal Teacher Professional Development
}

\author{
Camille Rutherford \\ Brock University
}

\begin{abstract}
While originally marketed to college students, Facebook has grown into a popular gathering space not just for students, but also for professionals who are seeking an opportunity to network with others and exchange ideas and resources. Within Facebook's gathering areas, thousands of teachers that can be observed engaging in discussions related to teaching and learning. Facebook provides teachers with an opportunity to engage in informal professional development that is participant driven, practical, collaborative, dynamic in nature and available 24 hours a day from any Internet connected location.
\end{abstract}

Keywords: Facebook; teaching and learning; social media 


\section{Facebook as a Source of Informal Teacher Professional Development}

\section{Purpose}

The public often perceives Facebook as being an adolescent playground ripe with juvenile gossip and social bullying. This negative perception might have dissuaded the academic community from becoming aware of the professional uses of this medium. While originally marketed to college students, Facebook has grown into a popular gathering space not just for students, but also for professionals who are seeking an opportunity to network with others and exchange ideas and resources. Within Facebook's gathering areas, thousands of teachers that can be observed engaging in discussions related to teaching and learning. The vast size of these groups, that number in the tens of thousands, and the hundreds of discussion topics that cover the full spectrum of educational issues, highlights the potential of this medium to support teacher development. The intent of this paper is to determine if the discussions that have taken place within the Ontario teachers - resource and idea sharing group can be considered professional development and if it adheres to the parameters of effective professional development.

\section{Significance}

Unlike traditional professional development, that is often fleeting in duration, narrow in focus and top-down in its creation and delivery (Barab, MaKinster, Moore, \& Cunningham, 2001; Togneri \& Anderson, 2003), social network sites like Facebook can be seen as creating informal opportunities for teachers to engage in professional development that is ongoing, collaborative, easily accessible, and free.

The vast and uncharted waters of social network sites remains to be explored as scholars currently have a limited understanding of who is using these sites, and why they are using them (boyd \& Ellison, 2007). Further exacerbating the need for research is the dramatic growth of these sites and their hundreds of millions of users (Beer, 2008; boyd \& Ellison, 2007; Golbeck, 2007). The large number of teachers, which number in the tens of thousands, who are engaging in the various Facebook teacher groups makes it imperative for researchers to examine this occurrence so that they can begin to consider the ramification for teacher development.

\section{Theoretical Framework}

This exploration of informal teacher professional development within the context of Facebook is guided by the literature related to teacher knowledge development (Shulman, 1987; Verloop, Van Driel, \& Meijer, 2001) and effective teacher professional development (Borko, 2004; Darling-Hammond, \& Mclaughlin, 1995; Nord, 2004; Smylie, Allensworth, Greenberg, Harris, \& Luppescu, 2001; Warren-Little, 2006; Wei, Darling-Hammond, Andree, Richardson, \& Orphanos, 2009).

As a reaction to the reform minded research of the 1980's that stressed the professionalization of teaching and the formulation of a knowledge base for teaching, Lee Shulman's influential paper published in 1987 developed a means to categorize this knowledge base. The categorization of general teaching principles served to "simplify the otherwise outrageously complex activity of teaching” (Shulman, 1987, p. 7). The seven categories that frame the knowledge teachers need to promote comprehension among students grew out of the existing literature regarding the qualities and understandings, skills and abilities, and traits and sensibilities that render someone a competent teacher (Shulman, 1987). These categories of knowledge essential to teaching included content knowledge; general pedagogical knowledge; 
curriculum knowledge; pedagogical content knowledge; knowledge of learners and their characteristics; knowledge of educational contexts; and knowledge of educational ends, purposes, and values, and their philosophical and historical grounds (Shulman, 1987). Consequently, attempts to enhance these areas of teacher knowledge fall under the realm of professional development that is often considered the sum total of formal and informal learning pursued and experienced by the teacher in a compelling learning environment (Fullan, 1995).

While formal learning is typically institutionally sponsored, highly structured and classroom-based informal learning typically does not fall within this framework. Although informal learning may take place within an institutional context, the control of learning rests primarily in the hands of the learner (Marsick \& Watkins, 2001). It is important to note that even though it may not be institutionally sponsored or highly structured, informal learning is generally intentional as it is usually a result of a need, motivation, or opportunity for learning (Marsick \& Watkins, 2001).

Professional development has traditionally been viewed as a formal activity that is often hierarchical in nature, as typically an "expert"' disseminates information to novices (Barab et al., 2001). Generally fleeting in duration and narrow in focus, the series of workshops, meeting, and institutes that were often pre-determined by district and state mandates (Barab et al., 2001; Togneri \& Anderson, 2003) have generally not been very successful in enhancing teacher knowledge and improving student achievement (Barab et al., 2001; Darling-Hammond \& Mclaughlin, 1995; Schlager \& Fusco, 2003; Togneri \& Anderson, 2003).

Where many traditional professional development methods had limited success, newer, more innovative methods that focus on ongoing growth activities may have a greater potential to affect positively teacher development (Hirsh, 2004). The dynamic nature of online professional development efforts may be helpful in addressing many of the shortcomings of traditional professional development programs. Unlike traditional professional development where the role of the teacher and learner are static, online teacher knowledge development is often more dynamic in nature where teachers have the opportunity to take on the role of learner as well as teacher (Warren-Little, 2006).

A review of the literature related to professional development has noted that effective PD is characterized as being:

- Sustained, on-going and intensive (Borko, 2004; Darling-Hammond \& Mclaughlin, 1995; Wayne, Yoon, Zhu, Cronen, \& Garet, 2008; Wei et al., 2009)

- Practical and directly related to local classroom practice and student learning (Borko, 2004; Darling-Hammond \& Mclaughlin, 1995; Hirsh, 2004; Nord, 2004; Wei et al., 2009)

- Collaborative and involving the sharing of knowledge (Borko, 2004; DarlingHammond \& Mclaughlin, 1995; Hirsh, 2004; Nord, 2004; Warren-Little, 2006)

- Participant driven and constructivist in nature (Borko, 2004; Darling-Hammond \& Mclaughlin, 1995; Wayne et al., 2008)

To overcome the pitfalls of traditional professional development efforts, contemporary PD should seek to include these four requirements. Interestingly, the dynamic nature of the Facebook discussion forums may be uniquely positioned to address informally a number of these requirements. 


\section{Facebook}

While it was not the first major social network site to appear, nor is it the largest online social network, Facebook with its 80 million users has come to dominate discussions related to social network sites (boyd \& Ellison, 2007). Facebook was created in 2004 at Harvard University as a means to facilitate student interaction and communication. It has since grown into an enormously popular "social utility that helps people communicate more efficiently with their friends, family and coworkers (Facebook, 2008).”

Central to the Facebook experience are the user created profiles where one can post descriptive details about themselves as well as pictures and video. These detailed descriptions facilitate the creation of networks of "friends." The ability to seek out and connect with old and new friends has fueled Facebook's exponential growth. While the site includes a number of other features, of paramount importance to this research is the Facebook Groups application. This feature allows users to join and create groups that are based on shared interests or activities (Facebook, 2008). A group can be public, where anyone can join, or private where the group's creator moderates its membership.

The ability to connect with other group members is facilitated by the presence of a members' list that includes each member's name, their profile picture, and a link to request to be added to their friend list. In addition to these networking features, each group page includes picture and video sharing applications that permits users to share these resources with the entire group.

Intra-group communication takes place via a word wall, where members can post general messages directed to the group as a whole or within a discussion forum. The much used discussion feature allows users to engage in specific conversations regarding a user-defined topic. It is the exchanges that take place within the discussion forum that are at the centre of this research.

A keyword search on Facebook for the word "teacher" indicates that there are over 500 public groups with the term teacher in its title. While some of these teacher groups are teacher fan and non-fan clubs that congregate around their like or dislike of a specific teacher, many are a gathering of educators that are interested in connecting with other educators to share ideas and resources. These teacher groups range from large collections of thousands of members from diverse locations to small groups that have a pre-existing offline relationship. The Facebook group at the centre of this investigation is the Ontario teachers - resource and idea sharing group. With over eight thousand members, the group is described as, "As Ontario teachers, we have a wealth of experience and useful ideas to share. We know what works, and what does not work. Let's share what we have discovered!” In addition to being a typical example of the many teacher groups on Facebook, this group was selected for study because the discussion that took place were often germane to the geographic area in which the author resides. Being a former classroom teacher and current teacher educator in Ontario, provided the author with additional insight into many of the contextual issues surrounding the discussion topics.

\section{Methodology/Data Sources}

Central to this investigation will be a qualitative and quantitative examination of the discussion topics and responding messages of the Ontario teachers - resource and idea sharing group. This moderately sized group has over eight thousand members. Over the course of 2007/2008 school 
year 278 discussion topics were created which resulted in 1,867 discussion posts. These discussion topics were examined to note the content of the discussion and to determine if these discussions adhere to the parameters of effective professional development.

Shulman's categorization of teacher knowledge was used to guide the content analysis of the discussions. Shulman's categories include:

- content knowledge,

- general pedagogical knowledge,

- curriculum knowledge,

- pedagogical content knowledge,

- knowledge of learners and their characteristics,

- knowledge of educational contexts, and

- knowledge of educational ends, purposes, and values, and their philosophical and

historical grounds (Shulman, 1987).

Of particular importance will be the frequency of posts that are related to pedagogical content knowledge. In addition to Shulman (1987), the work of Warren-Little (2006) also notes the importance of pedagogical content knowledge as being key to teacher professional development as it enables teachers to transform the content and epistemology of a subject discipline for purposes of teaching (Warren-Little, 2006).

To be included in this study, a discussion had to consist of at least two posts by two different people. Opening posts that received no response were excluded, as without out the input of another individual it cannot be considered a discussion. The 62 solo posts that were excluded from this study were often thinly disguised marketing attempts by authors, website developers, or salespeople trying to draw users to their external websites. It is important to note that even though these posts did not attempt to engage users in a discussion, many of these solo posts were still related to the education process.

Once the solo posts were excluded from the sample, 187 opening discussion posts were coded using Shulman's categorization of teacher knowledge and two additional codes. The code of “other” was used when Shulman's categories could not be adequately applied to discussion topic (see Table 1).

\title{
Table 1.
}

Coding categories

\section{Coding Categories in Alphabetical Order}

\author{
Content Knowledge \\ Curriculum Knowledge \\ Employment
}

General Pedagogical Knowledge

Knowledge of Educational Contexts 


$$
\begin{aligned}
& \text { Knowledge of Educational Ends } \\
& \text { Knowledge of Learners } \\
& \text { Other* } \\
& \text { Pedagogical Content Knowledge }
\end{aligned}
$$

* author created category

After an initial review of the opening discussion posts, it became apparent that there was a significant number of posts that pertained to teacher employment. While these posts were germane to the 'Knowledge of Educational Context' category that includes knowledge of school district administration, the author thought it would be prudent to create an additional category of "Employment." Consequently, in addition to Shulman's seven categories of teacher knowledge, the two additional codes of "Other" and "Employment" were also used (see Table 1).

A qualitative coding program called HyperResearch was used to facilitate the coding process. The text of each discussion was copied from the Facebook site and saved as a separate text file. These files were imported into HyperResearch where the text of the initial discussion post was reviewed and then coded by the author. A report of the discussion text and its assigned code were then exported into an Excel spreadsheet so that the quantitative analysis could take place.

An additional researcher coded a randomly chosen sub-set of the discussion posts to determine the level of inter-rater reliability for the coding process. After coding 50 discussion posts the percentage of agreement was $80 \%$. This can be considered an excellent level of agreement and indicates a high degree of consistency for the coding process (Fleiss, Levin, \& Paik, 2003).

After determining that the number of participants that created a discussion post was 384, the level of collaboration was determined by investigating the number of participants per discussion topic. A key facet of effective teacher professional development is that it is ongoing. To determine if participation in the discussion forum is ongoing the frequency of participation of all 384 participants was examined.

\section{Findings}

\section{Discussion Post Content Analysis}

The code that was most frequently applied was that of Pedagogical Content Knowledge. With 49 posts, this made up 26.2\% of the initial discussion posts (see Table 2). This code was applied to posts that were related to participants seeking advice and ideas about how to make their lessons for a specific subject more creative, engaging, interactive, or fun (See the Appendix for example posts for each category). 
Table 2.

Category Frequency

\begin{tabular}{|l||l|l||}
\hline \multicolumn{1}{|l|}{ Category } & Number of Opening Discussion Posts & Percent \\
\hline Pedagogical Content Knowledge & 49 & $26.2 \%$ \\
Employment & 42 & $22.5 \%$ \\
Curriculum Knowlege & 37 & $19.8 \%$ \\
General Pedagogical Knowledge & 18 & $9.6 \%$ \\
Other & 17 & $9.0 \%$ \\
Knowledge of Educational Contexts & 16 & $8.5 \%$ \\
Knowledge of Learners & 5 & $2.7 \%$ \\
Content Knowledge & 0 & $1.6 \%$ \\
Knowledge of Educational Ends & 3 \\
\hline
\end{tabular}

In contrast to the Pedagogical Content Knowledge posts where the users were soliciting ideas related to a specific content area, the 37 Curriculum Knowledge posts were most often seeking curricular resources for a specific subject area and grade level. The educators that created these types of posts were frequently seeking online resources or recommendations of helpful websites.

The 18 opening discussion posts that were coded as General Pedagogical Knowledge were those that were related to the general knowledge of principles and strategies for curriculum and classroom management. The majority of these posts sought advice related to classroom management. These posts often pertained to educators seeking advice in dealing with specific behavioural challenges.

The code of "Other" was applied to any discussion post that did not adequately fall under any of Shulman's categories. While the 17 opening discussion posts that received this code may be related to the educational process, they do not readily address any component of teacher knowledge.

As noted earlier, opening discussion posts that fell under the category of Knowledge of Educational Contexts were sub-divided to create a new sub-category of Employment. The remaining 16 posts addressed issues pertaining to teacher knowledge of school or school district administration or policies.

The Employment code was applied to $22.4 \%$ or 42 posts. This subset of the Knowledge of Educational Context category was applied to posts that were related to securing employment as a teacher or gaining admission to a teacher education program. Unlike many other jurisdictions, the Canadian province of Ontario has a significant surplus of teachers to fill a 
limited number of jobs. As a result, a large number of posts in this category expressed frustration about securing a full time teaching position.

The five discussion posts that were coded as pertaining to Knowledge of Learners \& their Characteristics were typically attempts to seek general advice and information about working with students with special needs, but did not request specific strategies or materials. The posts were often about developing a greater understanding of the needs or characteristics of ESL, Aboriginal, or special education students.

The three opening discussion posts that were coded as being related to Content Knowledge pertained to an educator's need to enhance their own knowledge of a specific content area. There were no discussion posts that were coded as Knowledge of Educational Ends. This code would have been applied to any posts that were related to the purposes, values, and philosophical and historical grounds of education.

\section{Participation Analysis}

Over the course of the 2007-2008 school year 384 Facebook users actively participated in the Ontario teachers - resource and idea sharing group. Once the solo discussion posts were eliminated, there was an average of 10 posts for each discussion topic. The discussion topic with the greatest number of posts was 110 .

While there was one user who created 78 posts over a seven-month period, the average number of posts created per user was 4.2. The frequency of participation was determined by counting the number of months in which the user created a discussion post. The average number of months of active participation was 1.79. This reveals that most users in this group were actively engaged in discussion for less than two months.

\section{Discussion}

The literature related to teacher professional development suggests that learning opportunities that are ongoing, practical, collaborative, and participant driven (Borko, 2004; DarlingHammond \& Mclaughlin, 1995; Hirsh, 2004; Nord, 2004; Smylie et al., 2001; Warren-Little, 2006; Wei et al., 2009) can be considered to effectively support teacher professional development and are associated with instructional improvements and improved student achievement (Smylie et al., 2001; Wayne et al., 2008).

The informal nature of Facebook participation guarantees that this form of professional development is participant driven. Unlike traditional forms of teacher professional development, where administrators or experts control the learning process, the participants of the Ontario teachers - resource and idea sharing group directed the discussions and were clearly in control of the learning process. As a result, the control of learning rested solidly in the hands of the learner (Marsick \& Watkins, 2001).

Even after subtracting the posts related to employment, it is still notable that $70 \%$ of the discussion topics were germane to Shulman's categorization of teacher knowledge. As a result, it is evident that the discussions that took place were practical and have the potential to directly impact teaching practice. Shulman's (1997) categories were based on his observations of teachers that displayed expertise in teaching. He noted that these categories should form the knowledge base of what a teachers should know and be able to do. 
Pedagogical content knowledge has been identified as being vital to overall teacher knowledge, and is perceived to have the greatest impact on teachers' classroom actions (Ball, Thames, \& Phelps, 2008; Gess-Newsome, 1999; Shulman, 1986, 1987; Verloop et al., 2001). The large number of discussion topics, that pertained to this category demonstrates the practical nature of these discussions that have the potential to influence teaching practice and student learning.

The number of posts per discussion highlights the collaborative and dynamic nature of these Facebook discussions. Each discussion topic had an average of 10 posts per discussion. Most often, this would take the form of a teacher in need creating a new discussion topic that solicited input regarding a particular classroom challenge or sought a resource or strategy that could be used to enhance their teaching practice. The end result was often that a number of group members would post their ideas or opinions as to what resource or strategy could be used to overcome the specified challenge. In contrast to traditional professional development methods where knowledge was transferred from an expert to the novices participating in the session (Villegas-Reimers, 2003), the Facebook discussions observed subscribed to a more active and constructivist learning process where the participants had the opportunity to be both the teacher and the student (Borko, 2004; Darling-Hammond \& Mclaughlin, 1995).

Prior research has noted that the traditional notions of in-service training should be replaced by opportunities for knowledge sharing where teachers have the opportunity to share what they know, discuss what they want to learn, and connect new concepts and strategies to their own unique contexts (Borko, 2004; Darling-Hammond \& Mclaughlin, 1995). The knowledge sharing and collaborative problem solving that took place in the Facebook discussions appear to adhere to this criterion.

Critics of traditional teacher professional development have frequently criticized the fleeting nature of many of these programs that attempt to support teacher knowledge (Tongneri \& Anderson, 2003; Wayne et al., 2008). This has caused many to cite ongoing participation to be an essential element of effective professional development (Darling-Hammond \& Mclaughlin, 1995; Smylie et al., 2001; Warren-Little, 2006; Wayne et al., 2008; Wei et al., 2009). While active participation in the discussion groups may not be as fleeting as traditional professional development models it would appear that it was not sustained for more than a few months.

It is important to note that one of the greatest limitations of the research undertaken is that it only documents active participation, when a participant has created a discussion post. This blind spot does not take into account opportunities when a participant may have simply read the discussion posts. As noted earlier, only 384 of the over 8,000 members of this Facebook group created a discussion post during the data collection period. Consequently, there is no way of knowing if the knowledge of these 'lurkers' was affected by simply reading the posts of the active group members. Consequently, the duration and scope of participation may in fact be may be greater than previously noted.

\section{Conclusion}

In addition to becoming one of the most popular social gathering places on the planet, Facebook has also become a notable professional forum as well. Within the plethora of Facebook teacher groups are thousands of educators creating hundreds of discussion posts that address the spectrum of educational issues. Consequently, it should be apparent that Facebook is more than an adolescent playground, but a powerful medium that teachers can visit to enhance their 
knowledge and teaching practice. This study has highlighted that teachers are using these groups and the discussions that take place as an opportunity to engage in informal professional development.

For years the most common form of professional development available to teachers was "staff development" or "in-service training" sessions, which usually consisted of workshops or short-term courses selected by administrators to provide teachers with new information on a particular aspect of their work (Villegas-Reimers, 2003). With the advent of web-based technologies, teachers can now engage in professional development that is participant driven, practical, collaborative, and available 24 hours a day from any Internet connected location. While these descriptors form some of the essential elements of effective teacher professional development (Borko, 2004; Darling-Hammond \& Mclaughlin, 1995; Nord, 2004; Smylie et al., 2001; Villegas-Reimers, 2003; Warren-Little, 2006; Wei et al., 2009), they also describe the features of the Facebook teacher discussion forums. Participation in these types of groups has the potential to enhance teaching practice as teachers are provided with access to a variety of collaboratively created discussions that address a myriad of teaching issues in a low risk, nonjudgmental environment that bears no cost to the participants or any educational institution.

Until the education community comes up with a formal means of professional development that is free, user friendly, and timely, Facebook teacher groups and similar forms of social media should be seen as an effective supplement to traditional teacher professional development. Consequently, instead of dissuading teachers from joining Facebook, and blocking access to similar social media sites, school districts and teachers' unions, should encourage and even support teacher participation in these informative, efficient, and affordable professional development opportunities. 


\section{References}

Ball, D., Thames, M., \& Phelps, G. (2008). Content knowledge for teaching: What makes it special? Journal of Teacher Education, 59(5), 398-407.

Barab, S. A., MaKinster, J. G., Moore, J. A., \& Cunningham, D. J. (2001). Designing and building an on-line community: The struggle to support sociability in the Inquiry learning forum. ETR\&D, 49(4), 71-96.

Beer, D. (2008). Social network(ing) sites...revisiting the story so far: A response to danah boyd \& Nicole Ellison. Journal of Computer-Mediated Communication, 12, 516-529.

Borko, H. (2004). Professional development and teacher learning: Mapping the terrain. Educational Researcher, 33(8), 3-15.

boyd, D., \& Ellison, N. B. (2007). Social network sites: Definition, history, and scholarship. Journal of Computer-Mediated Communication, 13(1).

Darling-Hammond, L., \& Mclaughlin, M. W. (1995). Policies that support professional development in an era of reform. Phi Delta Kappan, 76.

Facebook. (2008). Facebook fact sheet. Retrieved June 7, 2008 from http://www.facebook.com/press/info.php?factsheet

Fleiss, J. L., Levin, B., \& Paik, M. C. (2003). Statistical methods for rates and proportions. San Francisco: John Wiley \& Sons.

Fullan, M. (1995). The limits and potential of professional development. In T. Guskey (Ed.), Professional development in education: New paradigms and practice (pp. 253-268). New York: Teachers College Press.

Gess-Newsome, J. (1999). Pedagogical content knowledge: An introduction and orientation. In J. Gess-Newsome \& N.G Lederman (Eds.), Examining pedagogical content knowledge (pp. 3-17). Dordrecht: Kluwer Academic Publishers.

Golbeck, J. (2007). The dynamics of web-based social networks: Membership, relationships, and change. First Monday, 12(11), 18.

Hirsh, S. (2004). Putting comprehensive staff development on target. Journal of Staff Development, 25(1), 12-15.

Marsick, V. J., \& Watkins, K. E. (2001). Informal and incidental learning. In New directions for adult and continued education (Vol. 89). San Francisco: Jossey-Bass.

Nord, P. (2004). Tailoring professional development for a better fit. Principal Leadership, 5(3), $16-21$.

Schlager, M. S., \& Fusco, J. (2003). Teacher professional development, technology, and communities of practice: Are we putting the cart before the horse? The Information Society, 19, 203-220.

Shulman, L. S. (1986). Those who understand: Knowledge growth in teaching. Educational Researcher, 15(2), 4-14.

Shulman, L. S. (1987). Knowledge and teaching: Foundations of the new reform. Harvard Educational Review, 57(1), 1-22. 
Smylie, M. A., Allensworth, E., Greenberg, R. C., Harris, R., \& Luppescu, S. (2001). Teacher professional development in Chicago: Supporting effective practice. Chicago, IL: Consortium on Chicago School Research.

Togneri, W., \& Anderson, S. E. (2003). Beyond islands of excellence. Washington, D.C: Learning First Alliance.

Verloop, N., Van Driel, J., \& Meijer, P. (2001). Teacher knowledge and the knowledge base of teaching. International Journal of Educational Research, 35(5), 441-461.

Villegas-Reimers, E. (2003). Teacher professional development: An international review of the literature. Paris: UNESCO: International Institute for Educational Planning.

Warren-Little, J. (2006). Professional community and professional development in the learning centered school. Alphareta, GA: National Educational Association.

Wayne, A. J., Yoon, K. S., Zhu, P., Cronen, S., \& Garet, M. S. (2008). Experimenting with teacher professional development: Motives and methods. Educational Researcher, 37(8), 469-479.

Wei, R. C., Darling-Hammond, L., Andree, A., Richardson, N., \& Orphanos, S. (2009). Professional learning in the learning profession: A status report on teacher development in the United States and abroad. Dallas, TX: National Staff Development Council. 


\section{Appendix}

\begin{tabular}{|c|c|c|}
\hline Category & $\begin{array}{l}\# \quad \text { of } \\
\text { Posts }\end{array}$ & Example Discussion Posts \\
\hline $\begin{array}{l}\text { Pedagogical } \\
\text { Content } \\
\text { Knowledge }\end{array}$ & 49 & $\begin{array}{l}\text { Does anyone have some creative ideas for the liquids and solids } \\
\text { unit? I would appreciate anything you can throw my way!!! } \\
\text { I'm starting Chapter } 6 \text { of the Grade } 6 \text { Nelson textbook } \\
\text { (multiplication/division) and was wondering if anyone had any } \\
\text { great lesson ideas for the first topic (factors/multiples, etc.) }\end{array}$ \\
\hline Employment & 42 & $\begin{array}{l}\text { I'm finding it incredibly difficult finding full time teaching work in } \\
\text { Ontario. Is anyone else experiencing this? Unless a PJ teacher has } \\
\text { their french qualifications, then it doesn't seem like full time \& } \\
\text { permanent work is a realistic goal. Having family members (or } \\
\text { good friends) working in a board also seems to help. } \\
\text { I was just wondering if anyone had any tips on what type of } \\
\text { questions will be asked in an interview for the supply list (public } \\
\text { and catholic)? Any help would be greatly appreciated. }\end{array}$ \\
\hline $\begin{array}{l}\text { Curriculum } \\
\text { Knowledge }\end{array}$ & 37 & $\begin{array}{l}\text { One of my grade } 6 \text { students has asked for help in improving his } \\
\text { handwriting as others often have trouble reading it. He is turning } \\
\text { over a new leaf in school, so I want to encourage him any way I } \\
\text { can, but don't know which resources to use for handwriting for } \\
\text { older students. Does anyone know of any resources for this? } \\
\text { I just accepted a position at a private high school, and I will be } \\
\text { teaching gr. } 9 \text { and } 10 \text { french. French is not one of my teachables, } \\
\text { but I have taken several french classes at college. Does anyone have } \\
\text { any online resources or good books that will help me teach these } \\
\text { two grades. }\end{array}$ \\
\hline $\begin{array}{l}\text { General } \\
\text { Pedagogical } \\
\text { Knowledge }\end{array}$ & 18 & $\begin{array}{l}\text { I have a student who tries to bait everyone all the time. When I say } \\
\text { no to something, he tries to debate the validity of the rule. He seems } \\
\text { to need a valid reason for everything, but I just don't have the time } \\
\text { to explain everything all day long ... I have } 25 \text { other students who } \\
\text { need my attention. He's very bright and refuses to do work, } \\
\text { knowing that he'll pass anyway. I've spoken one on one and asked } \\
\text { whether this is acceptable at home, he said no and added that he } \\
\text { does it at school because he can get away with it here. Any } \\
\text { suggestions? } \\
\text { I've just landed a job teaching math and science to a grade } 7 / 8 \text { split }\end{array}$ \\
\hline
\end{tabular}




\begin{tabular}{|c|c|c|}
\hline & & $\begin{array}{l}\text { and to a grade } 9 \text { class on a first nations reserve. Very small classes } \\
\text { with very big behavioural issues and about half on IEP's, mostly for } \\
\text { reading LDs, who have had a succession of supply teachers since } \\
\text { September. These kids are bouncing off the walls. My main worry } \\
\text { is classroom management; what sort of plan can I implement that } \\
\text { will encourage these kids to work with me to create a productive } \\
\text { learning atmosphere? }\end{array}$ \\
\hline Other & & $\begin{array}{l}\text { I'm teaching a } 5 / 6 \text { class and would love to give them something } \\
\text { small for Christmas, but I am having a hard time thinking of cheap } \\
\text { ideas for this age group. Does anyone have any ideas? Thanks! } \\
\text { I'm looking for old magazines for a school project. They don't have } \\
\text { to be in good condition, since I'm mostly interested in the covers. I } \\
\text { would prefer not to print covers off the internet, as I'm trying to } \\
\text { recycle/re-use unwanted magazines. If you know where in Ottawa I } \\
\text { could obtain old magazines free of charge, or if you have old } \\
\text { magazines you'd like me to take off your hands, please post here or } \\
\text { send me a message. }\end{array}$ \\
\hline $\begin{array}{l}\text { Knowledge of } \\
\text { Educational } \\
\text { Contexts }\end{array}$ & 16 & $\begin{array}{l}\text { How much of your own money did you spend on classroom } \\
\text { decorations and materials when you started your first full time } \\
\text { position? What kind of materials and funds did the school start you } \\
\text { off with? } \\
\text { I have heard rumblings from teachers in other boards that some } \\
\text { boards are looking to add a November break to the school term, a } \\
\text { la, the university/college reading week. I am curious to see other } \\
\text { teachers opinion about this, both pro and con, as I think it may be a } \\
\text { good idea but know that there are definite draw backs. I personally } \\
\text { remember how much I appreciated the break at university, it came } \\
\text { at a time right before "the crunch" hit and was a great stress } \\
\text { reliever. I always felt refreshed and ready to return. I also think it } \\
\text { would be a great travel option for parents who take their children } \\
\text { out of school before Christmas because it is cheaper to travel, this } \\
\text { way all of the students would be gone at the same time, rather than } \\
2 \text { one week and } 3 \text { the next. What do you think? Is adding a } \\
\text { November break a good option? }\end{array}$ \\
\hline $\begin{array}{l}\text { Knowledge of } \\
\text { Learners \& } \\
\text { their } \\
\text { Characteristics }\end{array}$ & 5 & $\begin{array}{l}\text { I'm a grade } 5 \text { teacher who was just informed today that I will be } \\
\text { doing planning time coverage } 2-3 \text { periods a week in our ASD } \\
\text { classroom. Does anyone have any suggestions or ideas, or what I } \\
\text { can do with the students? }\end{array}$ \\
\hline
\end{tabular}




\begin{tabular}{|c|c|c|}
\hline & & $\begin{array}{l}\text { I'm teaching a } 1 / 2 / 3 \text { split in a very small school in a remote } \\
\text { Northern community of Ontario. Mainly Native population, largely } \\
\text { low levels academically, and a whole lot of behavioural stuff. Any } \\
\text { ideas about anything at all would be awesome! }\end{array}$ \\
\hline $\begin{array}{l}\text { Content } \\
\text { Knowledge }\end{array}$ & 3 & $\begin{array}{l}\text { Help!! I found out that I will be teaching the recorder during my } \\
\text { practicum. I don't play any instrument nor did I ever learn to read } \\
\text { music! Can anyone suggest a good resource that I can use to } \\
\text { quickly teach myself the basics then teach the grade 5's with? }\end{array}$ \\
\hline $\begin{array}{l}\text { Knowledge of } \\
\text { Educational } \\
\text { Ends }\end{array}$ & 0 & \\
\hline
\end{tabular}

